\title{
Weak Polygyny in California Sea Lions and the Potential for Alternative Mating Tactics
}

\author{
Ramona Flatz*, Manuela González-Suárez ${ }^{\text {aa }}$, Julie K. Young ${ }^{\text {abac }}$, Claudia J. Hernández-Camacho ${ }^{\text {ad }}$, \\ Aaron J. Immel, Leah R. Gerber
}

School of Life Sciences, Arizona State University, Tempe, Arizona, United States of America

\begin{abstract}
Female aggregation and male territoriality are considered to be hallmarks of polygynous mating systems. The development of genetic parentage assignment has called into question the accuracy of behavioral traits in predicting true mating systems. In this study we use 14 microsatellite markers to explore the mating system of one of the most behaviorally polygynous species, the California sea lion (Zalophus californianus). We sampled a total of 158 female-pup pairs and 99 territorial males across two breeding rookeries (San Jorge and Los Islotes) in the Gulf of California, Mexico. Fathers could be identified for 30\% of pups sampled at San Jorge across three breeding seasons and 15\% of sampled pups at Los Islotes across two breeding seasons. Analysis of paternal relatedness between the pups for which no fathers were identified (sampled over four breeding seasons at San Jorge and two at Los Islotes) revealed that few pups were likely to share a father. Thirty-one percent of the sampled males on San Jorge and $15 \%$ of the sampled males on Los Islotes were assigned at least one paternity. With one exception, no male was identified as the father of more than two pups. Furthermore, at Los Islotes rookery there were significantly fewer pups assigned paternity than expected given the pool of sampled males $(p<0.0001)$. Overall, we found considerably lower variation in male reproductive success than expected in a species that exhibits behavior associated with strongly polygynous mating. Low variation in male reproductive success may result from heightened mobility among receptive females in the Gulf of California, which reduces the ability of males to monopolize groups of females. Our results raise important questions regarding the adaptive role of territoriality and the potential for alternative mating tactics in this species.
\end{abstract}

Citation: Flatz R, González-Suárez M, Young JK, Hernández-Camacho CJ, Immel AJ, et al. (2012) Weak Polygyny in California Sea Lions and the Potential for Alternative Mating Tactics. PLoS ONE 7(3): e33654. doi:10.1371/journal.pone.0033654

Editor: Brock Fenton, University of Western Ontario, Canada

Received September 1, 2011; Accepted February 17, 2012; Published March 14, 2012

Copyright: (c) 2012 Flatz et al. This is an open-access article distributed under the terms of the Creative Commons Attribution License, which permits unrestricted use, distribution, and reproduction in any medium, provided the original author and source are credited.

Funding: The research was supported by the National Science Foundation (Grant no. 0347960 to LG). Dr. González-Suárez was funded in part by the European Community's Seventh Framework Programme (FP7/2007-2013; http://cordis.europa.eu/fp7) under grant agreement $\mathrm{n}^{\circ} 235897$ and the Spanish Ministry of Science and Innovation (CGL2009-07301/BOS and BES-2010-034151). The authors are grateful for a grant provided to Dr. Hernández-Camacho from Consejo Nacional de Ciencia y Tecnología (Scholarship No. 95802). The funders had no role in study design, data collection and analysis, decision to publish, or preparation of the manuscript.

Competing Interests: The authors have declared that no competing interests exist.

* E-mail: Ramona.Flatz@gmail.com

wa Current address: Department of Conservation Biology, Estación Biológica de Doñana-CSIC, Sevilla, Spain

ab Current address: Predator Research Facility, United States Department of Agriculture-Wildlife Services-National Wildlife Research Center, Logan, Utah, United States of America

ac Current address: Department of Wildland Resources, Utah State University, Logan, Utah, United States of America

ad Current address: Laboratorio de Ecología de Pinnípedos "Burney J. Le Boeuf", Centro Interdisciplinario de Ciencias Marinas, Instituto Politécnico Nacional, La Paz, Baja California Sur, México

\section{Introduction}

Polygyny, where one male mates with multiple females within a breeding season, is common among species where females bare the burden of gestation and care of offspring. Unconstrained by parental duties, a male's reproductive success is only limited by the number of females he can fertilize [1,2]. Aggregations of sexually receptive females allow males to monopolize groups of females [3] and it is the ensuing competition among males for access to potential mates that determines the degree of polygyny, or variation in male reproductive success [1-3]. It follows that male behavior during the breeding season has been used to infer the mating system and degree of polygyny within a population. However, the use of molecular genetic techniques in the study of mating systems has highlighted discrepancies between behavioral and genetic mating systems [4]. Indeed, paternity analysis in polygynous mating systems has revealed that males may not always be as successful at monopolizing access to breeding females as assumed from behavioral observations and theory [5-7]. In this study we use genetic tools to explore the mating system of a behaviorally polygynous species, the California sea lion (Zalophus californianus) in the Gulf of California, Mexico.

Pinnipeds (seals and sea lions) exhibit a variety of mating strategies which range from monogamy (e.g., largha seal, Phoca largha) to strong polygyny (e.g., elephant seals, genus Mirounga, Steller sea lion, Eumetopias jubatus) [8], making them ideal for the study of mating systems. Polygyny is facilitated by the aggregation of females during the breeding season as they haul out to give birth and nurse their pups [8-15]. Males defend spatially stable territories within a rookery and females either 1) mate with the male whose territory they primarily occupy (i.e., resource defense polygyny); or 2) freely move between male territories and select mates based on territorial displays, creating a lek-like system $[8,10]$. 
California sea lions breed from May to August on islands along the Pacific coast of the continental U.S. and the Baja peninsula, as well as the Gulf of California, Mexico [8,16,17]. In May and June, female California sea lions haul out and give birth to a single pup [18] which they nurse for about five days before leaving the breeding colony, or rookery, on short foraging trips lasting approximately three days [19]. During the breeding season, pups have very limited mobility and are dependent on their mother's milk for survival. Thus, females routinely return to their pupping site to nurse [8]. Adult males, which are nearly three times larger than females [20], defend territories occupied by females and pups [9,21-23]. Overall, the species' high sexual dimorphism, and male territorial behavior are suggestive of moderate to strong polygyny $[8,9,15,24,25]$.

Sea lion populations in the Gulf of California (Gulf) represent an interesting study system for several reasons. First, in the Gulf adult males actively defend territories with male tenure averaging around two weeks [26] but extending more than six weeks in some cases [19]. Although males defend territories, direct observation of copulations is rare at our study sites [19] compared to other California sea lion rookeries $[14,19]$. Second, female sea lions in the Gulf spend a considerable portion of their time at the rookeries in the water. This behavior is presumably a thermoregulatory response to exposure to the extremely high temperatures (up to $45^{\circ} \mathrm{C}$ ) in the Gulf $[19,27]$. In the water, females have greater mobility which likely limits the ability of males to monopolize them and may reduce the degree of polygyny [19]. Finally, there is a prolonged period between parturition and estrous, which extends for $>30$ days on average for females in the Gulf [18], as compared to 21 days for females off the California coast [14]. Thus, females within the Gulf become sexually receptive at a time when they are increasingly mobile and routinely leave the island on foraging trips when maturing pups are able to survive for several days between nursing bouts.

The extent to which these characteristics of sea lion breeding biology and behavior in the Gulf populations affect the mating dynamics is unclear, but it raises interesting questions about the mating system in these populations. In particular, it has been suggested that sea lions may exhibit a lek-like mating system where males defend territories and females move freely between territories to select mates $[18,19,21]$. This is in contrast to classic resource defense polygyny where sexually receptive females mate with the male whose territory they occupy. Alternatively, Odell [14] theorized that female movement in sea lions may facilitate alternative mating tactics, reducing male reproductive skew and, perhaps, even giving non-territorial males an advantage. The lack of genetic studies to validate these competing hypotheses has left the debate over the nature of California sea lion mating systems largely unresolved. In response to this need for research on the genetic mating system of California sea lions, we used genotype data from 14 polymorphic microsatellite loci to evaluate the type of polygyny (resource defense vs. a lek-like system), the degree of male reproductive skew, and the potential for alternative mating tactics present at three breeding sites on two sea lion rookeries in the Gulf.

\section{Methods}

\section{Ethics statement}

All procedures were approved by the Arizona State University Animal Care and Use Committee (07-918R). Data collection was authorized by the Secretaría de Medio Ambiente y Recursos Naturales (SEMARNAT, Oficio num/SGPA/DGVS/05325/05, 03269/06, 02709/07, and 03018/08). Samples were imported from Mexico under permits by SEMARNAT (Autorización no. 20215, 21572, 23010, and 24575) and the US National Marine Fisheries Service (no. 782-1694-02).

\section{Study sites}

For this study we selected two sea lion rookeries in the Gulf which had been the subject of behavioral research since 2004 [2830], San Jorge and Los Islotes Islands (Fig. 1). These rookeries support sea lion populations of approximately 4,000 and 500 individuals, respectively [17]. Field research took place from 2005 to 2008 at San Jorge and from 2006 to 2008 at Los Islotes. Each field season consisted of 2-3 trips (each lasting 5-10 days) in June, July, and August. During each trip we collected behavioral data and tissue samples from two study sites on Los Islotes and one on San Jorge (Fig. 1). Study sites were representative of typical sea lion habitat, characterized by concave stretches of the coastline yielding a relatively high concentration of females and pups [31].

At San Jorge, females, pups, and territorial males occupy virtually the entire coastline. Our study site included a section of the coast with a discrete cobble cove and up to eight male territories where we conducted behavioral observations and captured pups. Because we observed some females and pups moving in and out of the study site along the coastline, we also collected tissue samples from individuals in neighboring areas extending approximately $80 \mathrm{~m}$ along the coast on either side of the cove. In 2008, we collected samples from males at seven additional areas across the rookery to investigate relatedness patterns. At Los Islotes, females and pups haul out primarily along three distinct areas of the coast due to the near vertical shoreline along other

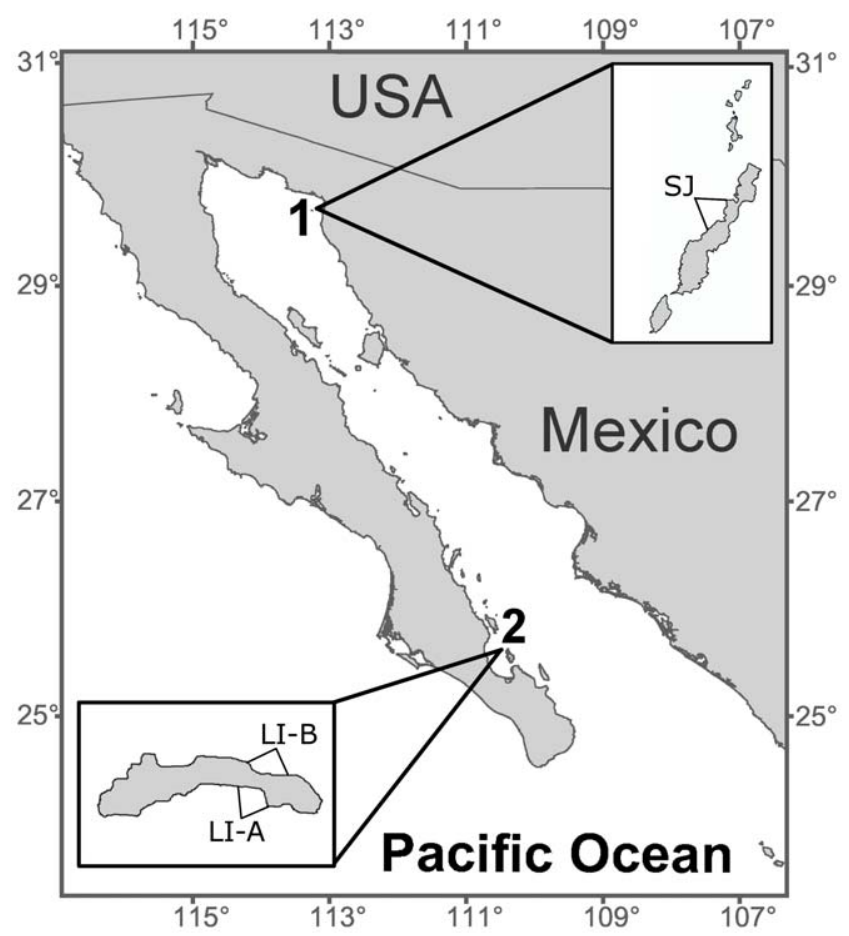

Figure 1. Map of the study sites at two sea lion rookeries in the Gulf of California. Insets indicate sampled study areas within each rookery. 1) San Jorge Island measures approximately $2.0 \mathrm{~km}$ between the northern islet and southern tip and $0.2 \mathrm{~km}$ at the widest point. Here, the marked area includes the study site and sampled adjacent areas. 2) Los Islotes Island is approximately $0.5 \mathrm{~km}$ long and $0.1 \mathrm{~km}$ at its widest point.

doi:10.1371/journal.pone.0033654.g001 
parts of the island. Of the three breeding areas on Los Islotes, the two areas with the highest concentration of females and pups were sampled in our study (Fig. 1).

\section{Tissue collection}

Tissue samples were obtained from pups by clipping a small $(<1 \mathrm{~g})$ sample of skin from the tip of a hind toe. Toe clips were placed in a $2 \mathrm{ml}$ screw top tube containing 95\% ethanol labeled with the date and a unique pup code. Scalpels and tweezers were cleaned between each biopsy with 100\% ethanol and a clean kimwipe ${ }^{\circledR}$. Individuals were identified with a unique haircut, which remained visible until late September of each year.

Tissue samples from adults were obtained using a crossbow and bolts fitted with custom made biopsy tips (Quality Manufacturing, Inc.) to which fishing line was attached for sample retrieval, (see [32]). To obtain samples of female-pup pairs for paternity analysis, we only took biopsies from females who were nursing a marked pup (from which a tissue sample had already been collected). California sea lions have been found to occasionally nurse nonfilial pups [33], however nursing behavior is still the most reliable indicator of true female-pup pairs and non-filial pairs can be easily identified by mismatches between female and pup genotypes; genotype mismatches are described in detail in the section on paternity assignment. Territorial males were identified based on scar patterns [21], allowing observers to track individual males between and throughout observation trips. At each island we obtained biopsies from territorial males within each study site, and on San Jorge we sampled additional territorial males adjacent to the site as described above.

\section{DNA extraction, amplification, and analysis}

DNA was extracted from tissue samples using a simple salting out procedure [34] and stored at $-20^{\circ} \mathrm{C}$. Once extracted, DNA was amplified at 14 microsatellite loci developed for California sea lions or closely related species (Table 1) in four multiplex polymerase chain reactions (PCR) using the Qiagen multiplex kit (Qiagen Inc.). We modified the microsatellite protocol outlined in the 2007 Qiagen Muliplex PCR Handbook so that $0.10 \mu \mathrm{M}$ of each primer was used per reaction, and total reaction volume was $7 \mu \mathrm{l}$. To monitor for contamination, negative controls were included in each manipulation. Fragment analysis was conducted on an ABI 3730 DNA Analyzer (Applied Biosystems, Inc.) and peaks were called by hand using the program GeneMapper v4.0. To ensure that each individual was only represented once in the database, the program GIMLET [35] was used to identify samples with identical genotypes. Samples with identical genotypes were considered to be from the same individual.

\section{Paternity assignment}

Because potential fathers were sampled a year prior to the year their offspring were sampled (i.e. the year of conception), we did not include female-pup pairs from the first field season for paternity assignment. We used the program CERVUs [36] to identify mismatches between female and pup genotypes (i.e., loci at which no alleles were shared). When mismatches were identified, we repeated extraction and/or PCR for the samples in question. If mismatches persisted, the female-pup pair was not used in paternity analyses. Therefore, only confirmed filial femalepup pairs were analyzed. Because the number of potential fathers available at each island was unknown, we assumed that $50 \%$ of the candidate males were sampled. This is the lowest fraction of candidate males advised by CERVUs; exclusion probabilities below this threshold may be inaccurate. We included all sampled adult males in the list of candidate fathers, meaning that CERVUS was allowed to consider all possible female-pup-male trios for each rookery, even if the male was not sampled the year of conception.

Genotyping error or the presence of null alleles can affect the results of paternity analysis (Hoffman et al. 1999). Repeated genotyping of 50 individuals at all 14 loci resulted in one, singlelocus genotype mismatch, giving a locus error rate of 0.0014. Even a low genotyping error rate can have a large impact on the outcome of genetic paternity assignment [37,38], so to further reduce errors in paternity assignment due to genotyping error, PCR and genotyping was repeated for all samples from femalepup-male trios that mismatched at two or fewer loci. To identify loci containing null alleles, the program CERVUS was used to test for deviations from Hardy-Weinburg equilibrium. Paternity assignments were only considered valid if a single candidate male matched a female-pup pair at all 14 loci and with $95 \%$ confidence (i.e., $\geq 95 \%$ chance of the male being the father).

We examined the probability that females are more likely to sire pups with males holding territories within each site than with males holding territories elsewhere on each rookery. The total number of males holding territories throughout the breeding season was estimated for both islands using census data from the entire island combined with information on male turnover within territories at our study sites. We then calculated the percentage of pups expected to be assigned paternity if females were equally likely to mate with any one of the territorial males, regardless of territory location. The expected and observed percentage of paternity assignments were compared using a binomial distribution where each pup that was assigned a father was considered a success and each pup not assigned a father was considered a failure. Paternity matches in which the father was not observed or sampled the year of conception were not included in this analysis. At San Jorge, where males holding territories directly adjacent to the study site were sampled, separate analyses were done including males from the adjacent areas and excluding them. All female-pup pairs were used in each analysis because movement of females and pups, particularly during capture sessions, made it impossible to differentiate between female-pup pairs that primarily occupied territories within the site and those that occupied territories in areas directly adjacent to the site. Data from sites A and B at Los Islotes were combined because movement of females and pups occurs between these two sites. To increase power, we combined information from all years at each site.

\section{Paternal relatedness}

Measurements of paternal relatedness between pups were used to estimate relative male reproductive success from the subset of female-pup pairs for which no father was identified. This was done using the Microsoft Excel Macro, DADSHARE [39] in which paternal haplotypes were derived from the genotypes of known female-pup pairs and systematically organized into a dendrogram according to relatedness. Clusters of pup genotypes consistent with a single male were identified to determine the minimum number of fathers necessary to account for the total pool of sampled pups at each island. This results in the highest possible ratio of pups per successful male and is thus expected to overestimate variance in male reproductive success. Therefore, to obtain a more accurate estimate of male reproductive success, mean pairwise relatedness between external branches of the dendrogram was compared to similar results from Monte Carlo simulations of five scenarios representing strong polygyny with either $1,2,3,4$, or 5 fathers siring all offspring (a few males contributing to the sample of pups), and five scenarios representing weak polygyny with each successful male siring 1, 2, 3, 4 or 5 pups (many males contributing to the sample of pups). For this analysis, female-pup pairs at each island 
Table 1. The number of observed alleles $\left(\mathrm{N}_{\mathrm{a}}\right)$, expected heterozygosity $\left(\mathrm{H}_{\mathrm{E}}\right)$, and non-exclusion probability for paternity assignment for 14 microsatellite loci.

\begin{tabular}{|c|c|c|c|c|c|c|}
\hline \multirow[b]{2}{*}{ Locus } & \multicolumn{3}{|c|}{ San Jorge } & \multicolumn{3}{|c|}{ Los Islotes } \\
\hline & $\mathbf{N}_{\mathbf{a}}$ & $\mathbf{H}_{\mathrm{E}}$ & Non-exclusion probability & $\mathbf{N}_{\mathbf{a}}$ & $\mathbf{H}_{\mathrm{E}}$ & Non-exclusion probability \\
\hline Pv09 $[50,51]$ & 6 & 0.482 & 0.7113 & 7 & 0.496 & 0.7122 \\
\hline Pv11 $[50,51]$ & 4 & 0.488 & 0.7209 & 5 & 0.544 & 0.6656 \\
\hline ZcCgDh4.7 [51] & 3 & 0.460 & 0.7902 & 3 & 0.461 & 0.7727 \\
\hline ZcCgDh5.16 [51] & 9 & 0.782 & 0.4293 & 6 & 0.693 & 0.5524 \\
\hline ZcCgDh1.8 [51] & 6 & 0.663 & 0.5925 & 6 & 0.666 & 0.5918 \\
\hline ZcCgDh48 [51] & 4 & 0.619 & 0.6684 & 5 & 0.536 & 0.7187 \\
\hline ZcCgDh5.8 [51] & 10 & 0.756 & 0.4432 & 11 & 0.815 & 0.3595 \\
\hline OrrFCB24 $[52,53]$ & 11 & 0.850 & 0.2994 & 11 & 0.840 & 0.3097 \\
\hline Pvc29 [53,54] & 16 & 0.842 & 0.3126 & 16 & 0.880 & 0.2479 \\
\hline ZcCgDh3.6 [51] & 6 & 0.630 & 0.5841 & 7 & 0.551 & 0.6467 \\
\hline Hg6.1 [51,53,55] & 5 & 0.635 & 0.6530 & 9 & 0.687 & 0.5655 \\
\hline $\mathrm{Hg} 8.10[53,55]$ & 5 & 0.541 & 0.7172 & 7 & 0.683 & 0.5668 \\
\hline 13HDZ462 [56] & 4 & 0.518 & 0.7592 & 4 & 0.634 & 0.6740 \\
\hline 71HDZ5A [56] & 9 & 0.632 & 0.5816 & 9 & 0.737 & 0.4286 \\
\hline Summary & 7.00 & 0.6355 & 0.0003 & 7.57 & 0.6611 & 0.0001 \\
\hline
\end{tabular}

Summary values include the average number of alleles and heterozygosity per locus, and the combined non-exclusion probability across all loci. doi:10.1371/journal.pone.0033654.t001

were combined for all years (2005-2008 on San Jorge, and 20072008 on Los Islotes). To evaluate the accuracy of the DADSHARE approach for our sample, the dataset of pups that were assigned fathers were analyzed independently and results were compared with the true ratio of pups per father as determined by paternity assignment.

\section{Results}

\section{Sample collection and genotype analysis}

At San Jorge, 118 female-pup pairs and 65 males were sampled. Of these, eight females were sampled twice in different years and four females were sampled in three different years, where each successive sampling included a new pup from that year. Thirty-six of the female-pup pairs were sampled in the first year (2005). These samples were used in analysis of paternal relatedness but not for paternity assignment because potential fathers (males from 2004) were not sampled. At Los Islotes, 40 female-pup pairs and 34 males were sampled. One female was sampled in both years. Each year we sampled approximately $75 \%$ of the territorial males identified in each site, except for Los Islotes rookery in 2006 when we only obtained biopsies from approximately $35 \%$ of the observed territorial males. The distribution of samples from males and female-pup pairs used in paternity analyses are shown in Table 2

No evidence of null alleles was found and all loci were in HardyWeinberg equilibrium. Repeated genotyping indicated a very low genotyping error rate of 0.0014 per locus and even when this error rate was doubled the outcome for paternity assignment did not change. No male that matched a female-pup pair at all loci was assigned paternity with less than $95 \%$ confidence and no male that mismatched a female-pup pair at one or more loci was assigned paternity with over $80 \%$ confidence. Thus, although we only assigned paternities when males matched female-pup pairs at all loci and with $95 \%$ confidence, identical results would have been obtained with a strict exclusion approach, or a likelihood based approach with either a $95 \%$ or $80 \%$ confidence threshold.

\section{Paternity assignment}

At San Jorge, paternity assignment included 82 female-pup pairs sampled from 2006-2008 and 65 territorial males sampled from 2005-2007. Paternities were assigned to 30\% of the femalepup pairs and included $31 \%$ of the sampled males. Twenty-three percent of sampled males both sired offspring and were observed at the rookery the year of conception and these paternities accounted for $23 \%$ of the pups. Of the 21 sampled males who held territories within the sample site (excluding adjacent areas), 29\% were assigned paternity to a total of $12 \%$ of the female-pup pairs. Only one of these pups was sired by a male that was not observed the year of conception.

At Los Islotes, paternity assignment included 40 female-pup pairs sampled in 2007-2008 and 34 territorial males sampled in 2006-2007. Fifteen percent of the sampled males could be assigned paternity to a total of $15 \%$ pups. When only paternities assigned to males that had been observed the year of conception were considered, these numbers were reduced to $12 \%$ of the males and $10 \%$ of the pups.

Both islands had similar patterns of paternity assignment with over $65 \%$ of the males not assigned any paternity. Most identified fathers were assigned paternity to a single pup (Fig. 2). Males with multiple assigned paternities had two offspring, except a single male who sired five pups born in 2007 and 2008. This male defended a territory within the study site on San Jorge.

Using census and male turnover data, we estimated 250 males held territories at San Jorge each year during the breeding season. Pups were more likely to be assigned a father from the pool of sampled males than would be expected if females were equally likely to mate with any one of the territorial males throughout the entire rookery $(p=0.0157$, power: $1-\beta=0.5466)$. This was slightly more pronounced when only those males holding territories within 
Table 2. Distribution of sampled individuals used in paternity analyses.

\begin{tabular}{|c|c|c|c|c|c|c|c|}
\hline \multirow[b]{2}{*}{ Year } & \multicolumn{3}{|l|}{ San Jorge } & \multicolumn{2}{|l|}{ Los Islotes A } & \multirow{2}{*}{\multicolumn{2}{|c|}{$\begin{array}{l}\text { Los Islotes B } \\
\text { Female-pup pairsMales }\end{array}$}} \\
\hline & Female-pup pairs & Males (site) & Males (adjacent areas) & Female-pup pairs & Males & & \\
\hline 2005 & 36 & 11 & 12 & - & - & - & - \\
\hline 2006 & 26 & 12 & 20 & - & 9 & - & 5 \\
\hline 2007 & 23 & 11 & 23 & 10 & 13 & 17 & 13 \\
\hline 2008 & 33 & - & - & 8 & - & 5 & - \\
\hline Total & 118 & 21 & 44 & 18 & 19 & 22 & 15 \\
\hline
\end{tabular}

Males that were present in multiple years are counted once for column totals. doi:10.1371/journal.pone.0033654.t002

the site were considered and males from adjacent areas were excluded $(p=0.0024$, power: $1-\beta=0.6874)$ (Table 3$)$. The number of years in which a male was observed at a site did not differ between males that were assigned paternities $(\mathrm{n}=6$, mean $\pm \mathrm{SD}=2.0 \pm 0.7$ years $)$ and males that were not $(\mathrm{n}=15$, mean $\pm \mathrm{SD}=1.8 \pm 0.5$ years).

At Los Islotes, we estimated a maximum of 50 males held territories throughout each breeding season. Sampled males were less likely to be assigned parentage than expected at random $(\mathrm{p}<0.0001$, power: $1-\beta=0.9994)$ (Table 3 ), suggesting that the estimated pool of territorial males on the island is not sufficient to account for the pups born on the island each year.

\section{Paternal relatedness}

Comparisons of paternal haplotypes from pups sampled over four years at San Jorge and two years at Los Islotes using the program DADSHARE revealed that a minimum of 39 males was necessary to account for the 69 pups with unknown fathers at San Jorge and a minimum of 19 males was necessary to account for the 34 pups with unknown fathers at Los Islotes. It was uncommon that groups of more than two pups were compatible with a single father, and five pups on Los Islotes constituted the largest group which could have potentially shared a father. Coincidentally, this was also the largest number of paternities assigned to a single male in this study (one male at San Jorge). The actual ratio of pups per male for the sample of pups with unknown fathers is probably closer to 1:1, as shown by comparing the observed mean values of paternal relatedness with values expected under simulations of varying numbers of pups per male (Fig. 3). These values are consistent with the paternity assignment results, where all but one male sired either one or two pups. Evaluating paternal relatedness patterns for the pool of pups with known fathers resulted in a pup per male ratio closer to 2:1 (Fig. 3). This suggests that DADSHARE may tend to overestimate the level of polygyny in our data.

\section{Discussion}

Many pinniped populations (including the California sea lion populations in this study) exhibit aggregations of breeding females and male territoriality, and, as expected given these behaviors, are often strongly polygynous [3,10,40]. For example, in the Antarctic fur seal (Arctocephalus gazella), less than $10 \%$ of successful males have been shown to share a quarter of assigned paternities [39], and a recent study of grey seals (Halichoerus grypus) revealed a mating system where nearly half the pups were fathered by $13 \%$ of territorial males present on the rookery [41]. Support for comparable polygyny levels in California sea lions comes from a behavioral study on copulation frequency and distribution at three rookeries (two off the California coast, and one in the Gulf of
California). At all three rookeries, a small proportion of the males accounted for the majority of observed copulations suggesting a strongly polygynous system [19]. However, our results show little reproductive skew among males, where only one male was identified as the father for more than two pups across four breeding seasons at San Jorge Island and three breeding seasons at Los Islotes Island. This male was assigned five paternities during his two-year tenure at the study site.

A recent paternity study of a closely related species, the Galapagos sea lion (Zalophus wollebaeki), revealed weak polygyny [7] comparable to our results. These authors found that in each breeding season, most sampled males sired no pups and most successful males sired only one or two pups with no male siring over four pups [7]. The authors hypothesized that their results are explained by the extended, non-synchronous breeding season of the Galapagos sea lion [42], which limits the ability of males to monopolize females and weakens polygyny. Interestingly, our research shows a nearly identical pattern of paternity assignments for a species with a synchronous mating season, suggesting that other factors may play a role in determining the extent of male reproductive skew. Odell [14] proposed that the ability to mate aquatically and a prolonged period between parturition and estrus may allow a less polygynous system to develop via a reduced ability of males to monopolize groups of receptive females. Like California sea lions in the Gulf, Galapagos sea lions are exposed to warm temperatures and have a prolonged period between birth and estrous [43]. These patterns suggest that changes in behavior associated with thermoregulation and an extended period between birth and estrous may be the critical factors limiting the ability of males to monopolize females. Whether asynchrony in mating also plays a role in limiting monopoly of females remains to be clarified. However, our results show that asynchrony is not required to reduce the levels of polygyny in otariids (fur seals and sea lions) and that weak polygyny may be more common than expected.

An important caveat of molecular paternity studies is the common failure to sample all potential breeders, which may lead to incorrect estimates of variance in male reproductive success if a few highly successful males are not sampled. We were able to address this issue by sampling female-pup pairs which allowed us to extrapolate the paternal contribution to the genotype of each pup when the father had not been sampled. The low levels of relatedness between inferred paternal genotypes supported the observed low level of male reproductive skew and excluded the possibility that we had failed to sample a few highly successful males. In addition, patterns of male reproductive skew were consistent in the two rookeries studied, which have genetically distinct populations [44] and are located in opposite ends of the 
A

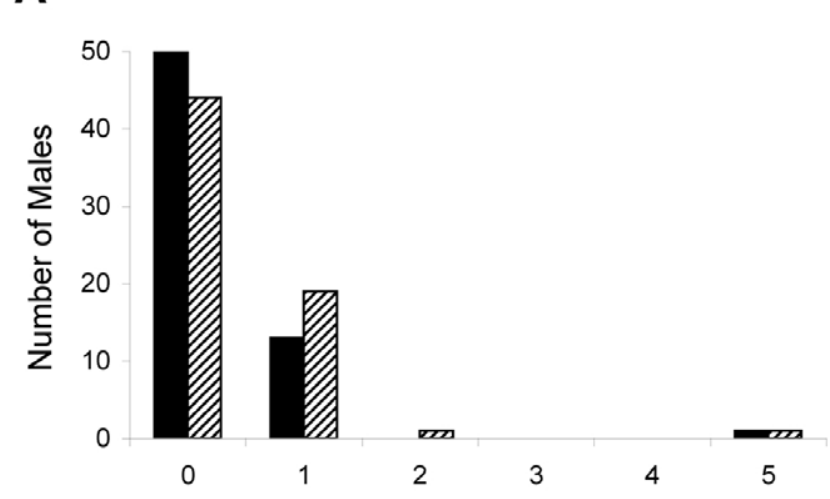

B

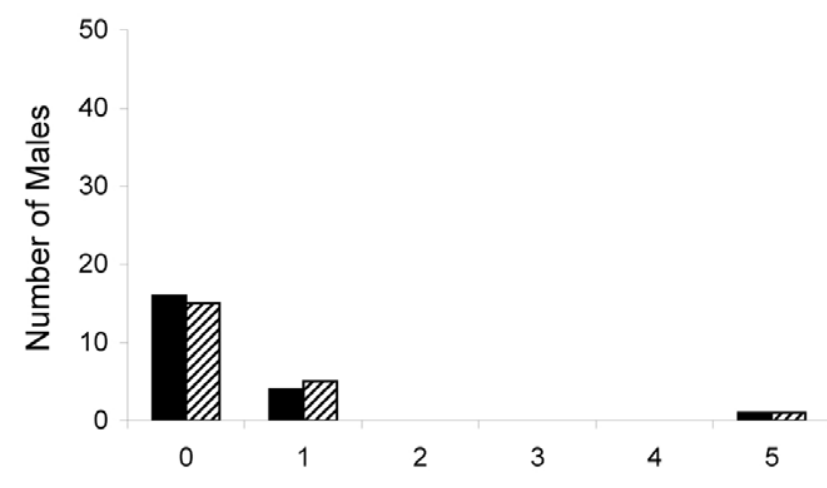

C

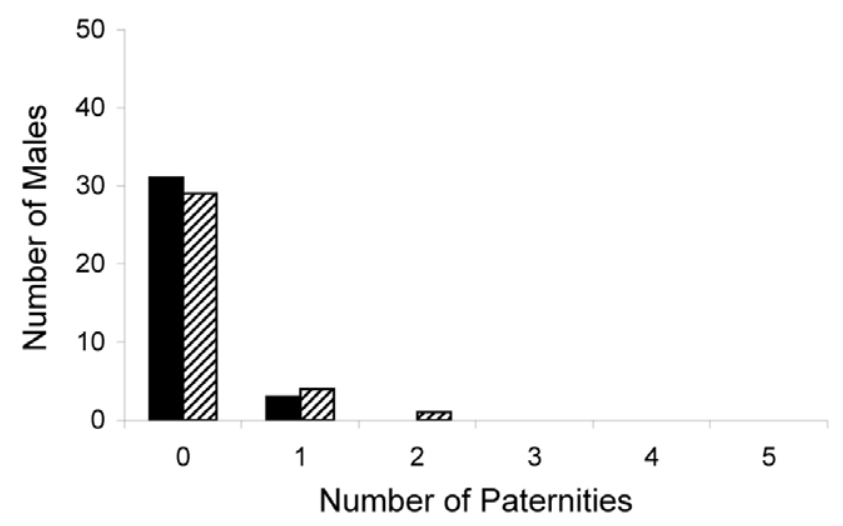

Figure 2. Distribution of cumulative male reproductive success. Bars represent the number of paternities assigned over a three year period to each of a) 65 territorial males on San Jorge including males both within the study site and along adjacent areas and b) 21 territorial males on San Jorge including only those males within the study site, and c) the number of paternities assigned over a two year period to each of 35 territorial males on Los Islotes. Solid bars include only those paternities where the father was identified at the rookery the year of conception, whereas hatched bars include all paternity assignments.

doi:10.1371/journal.pone.0033654.g002

Gulf. Therefore, the observed weak levels of polygyny are likely widespread among sea lions in the Gulf, and not an artifact of sampling errors or of unique features in the sampled rookeries.

In pinnipeds, territorial behavior evolved as a way for males to monopolize groups of sexually receptive females thereby improving the reproductive success of territorial males $[9,11,12]$. The ability of males to monopolize females was not well supported by our paternity assignment results, as only a small fraction of femalepup pairs were assigned fathers that held territories at our study sites. This suggests that although female presence determines territory locations within a rookery [14], holding a territory does not guarantee matings with nearby females. Therefore, the direct benefits of male territoriality are unclear. Some authors have suggested territories could play a symbolic role akin to male displays in a lek, in that females are free to select mates from territorial males throughout a rookery [19,21]. The pattern of paternity assignment at San Jorge provides some support for a leklike mating system. Specifically, females tend to mate with territorial males near their pupping site and the number of males holding territories at the rookery is sufficient to account for the number of pups born each year. Contrary to our results, a symbolic role of territoriality should still result in high variation in male reproductive success, as only the most fit males (as determined by females) will secure the majority of matings [24]. This lek-like mating system has been documented in an Antarctic fur seal rookery where sexually receptive females move between male territories and seem to exert choice for males with high multi locus heterozygosity [45]; genetic paternity assignment at this rookery showed large variation in male reproductive success as expected in a lek-like mating system [39]. A recent study at one South American sea lion colony (Otaria byronia) also found strong support for a lek-like mating system, here females were observed briefly leaving their pupping site to solicit matings from nearby territorial males [46]. In this study, behavioral observations indicated high polygyny with $14 \%$ of the territorial males participating in $50 \%$ of all copulations [46]. In contrast to these studies, mating success did not vary significantly among territory holders at our study sites. This is confounded by the existence of variation in territorial behavior, where males more actively defend territories in which more females are present [30], which suggests that there is variation in territory quality (or the potential reproductive benefit to the territory holder) which can be measured by female presence.

Given the possibility of alternative mating tactics, the presence of breeding, non-territorial males could reduce male reproductive skew while maintaining an evolutionary advantage of territoriality. In this scenario, we expect that some males will maximize their fitness by defending territories whereas others (possibly smaller, less aggressive males) likely perform poorly as territory holders and will have a better chance of reproductive success by adopting an alternative mating tactic. Although some individuals will be more successful as non-territorial males than they would as territory holders, average reproductive success will always be highest for territorial males $[47,48]$. If breeding, non-territorial males are all equally likely to sire offspring, in scenarios where these males greatly outnumber territorial males we would expect a reduction in overall male reproductive skew. For instance, if non-territorial males were able to secure $80 \%$ of the matings (this is the most extreme scenario justified by our data), even a large reproductive skew between territorial males for the remaining $20 \%$ of matings would be diluted when considering all matings.

The possibility that non-territorial males may regularly contribute to reproduction is supported by the fact that, on Los Islotes, females were less likely to sire pups with males which held territories within the study sites than expected at random (Table 3) and by the paucity of observed copulations at both rookeries. Seven-hundred and twenty observation hours at each site across four breeding seasons resulted in an average of only one copulation every two years per site. It is possible that copulations occur more frequently at night as a mechanism to prevent 
Table 3. Comparisons of observed and expected rates of paternity assignment.

\begin{tabular}{|c|c|c|c|c|c|c|}
\hline Year & Males (t-1) & $\begin{array}{l}\text { Female- pup } \\
\text { pairs }\end{array}$ & $\begin{array}{l}\text { Observed } \\
\text { paternities }\end{array}$ & $\begin{array}{l}\text { Expected } \\
\text { paternities }\end{array}$ & p-value & $1-\beta$ \\
\hline \multicolumn{7}{|l|}{ San Jorge } \\
\hline 2006 & 23 & 15 & $2(13.33 \%)$ & $1.4(9.20 \%)$ & 0.3082 & 0.0394 \\
\hline 2007 & 33 & 22 & $6(27.27 \%)$ & $2.9(13.20 \%)$ & 0.0390 & 0.3811 \\
\hline 2008 & 34 & 33 & $7(21.21 \%)$ & $4.5(13.60 \%)$ & 0.1411 & 0.1440 \\
\hline $2006-2008$ & 28 & 70 & 15 (21.43\%) & $8.4(12.00 \%)$ & 0.0157 & 0.5466 \\
\hline \multicolumn{7}{|c|}{ San Jorge (excluding adjacent areas) } \\
\hline 2006 & 11 & 15 & $2(13.33 \%)$ & $0.7(4.40 \%)$ & 0.0521 & 0.3188 \\
\hline 2007 & 12 & 22 & $3(13.64 \%)$ & $1.1(4.80 \%)$ & 0.0388 & 0.1364 \\
\hline 2008 & 11 & 33 & $4(12.12 \%)$ & $1.5(4.40 \%)$ & 0.0280 & 0.3626 \\
\hline 2006-2008 & 11.3 & 70 & 9 (12.86\%) & $3.2(4.53 \%)$ & 0.0024 & 0.6874 \\
\hline \multicolumn{7}{|l|}{ Los Islotes } \\
\hline 2007 & 14 & 27 & $2(7.41 \%)$ & $7.56(28.00 \%)$ & 0.0182 & 0.6774 \\
\hline 2008 & 26 & 13 & $1(7.69 \%)$ & $6.76(52.00 \%)$ & 0.0022 & 0.9294 \\
\hline 2007-2008 & 20 & 40 & $3(7.50 \%)$ & $7.16(40.00 \%)$ & $<0.0001$ & 0.9994 \\
\hline
\end{tabular}

Paternity assignment rates for San Jorge include all sampled territorial males and only those males sampled within the study site (excluding adjacent areas). At Los Islotes data from sites A and B were combined. The males for each year were actually sampled the year of conception ( $t-1)$. Expected paternities are calculated under the assumption females are equally likely to mate with any territorial male, regardless of territory location. P-values from a two-tailed binomial test and power (1- $\beta$ ) for $\mathrm{p}=0.05$ are reported.

doi:10.1371/journal.pone.0033654.t003

San Jorge

Los Islotes
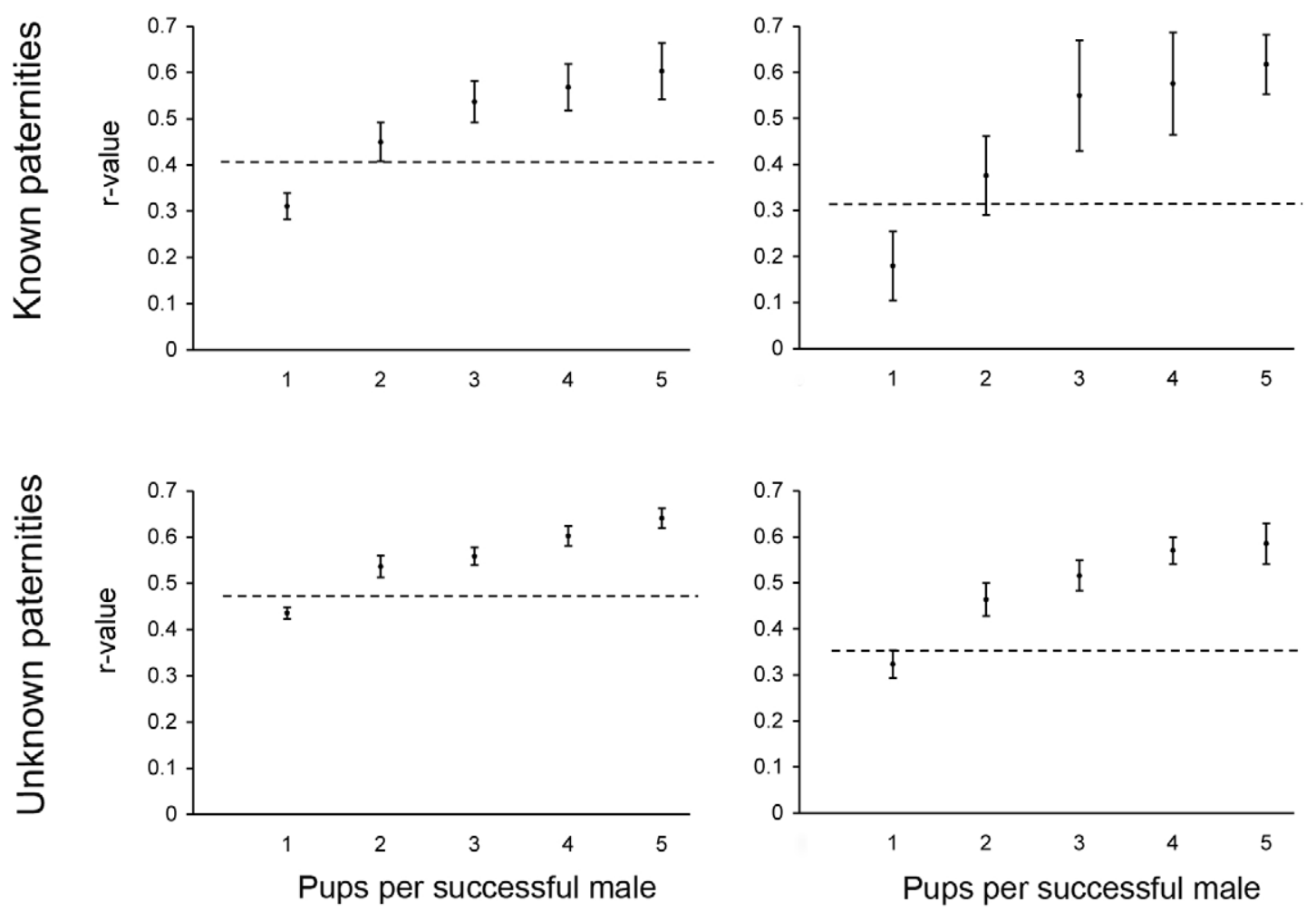

Figure 3. Observed paternal relatedness compared with expected values over a range of polygyny levels. Expected values of average paternal relatedness ( $r$-values) between pups if each successful male sires 1, 2, 3, 4 or 5 pups. Error bars represent $+/-$ one standard deviation. Horizontal lines represent the observed $r$-values for each pool of sampled pups. At each of the two rookeries, separate analyses were done for pups that were assigned fathers (known paternities) and pups whose fathers could not be assigned (unknown paternities). In all cases observed r-values fall between what would be expected if each successful male sired just one or two pups.

doi:10.1371/journal.pone.0033654.g003 
overheating in high daytime temperatures. A cumulative 20 hours of nighttime observations conducted with night vision goggles on San Jorge throughout July of 2008 resulted in no observed copulations. Thus, although nighttime observations were limited, it seems unlikely that copulation rate dramatically increases at night. The lack of observations suggests copulations may be occurring outside the rookeries' boundaries, such that some males intercept females traveling to and from the rookery on foraging trips. Strong evidence for a similar offshore, nonpolygynous mating tactic has been documented in the southern elephant seal (Mirounga leonina), a species that was previously thought to only mate at terrestrial breeding sites dominated by a few highly territorial males [49]. The alternative of sneaker males entering the sites and territories to mate is unlikely given that copulations were rarely observed (those that were observed always involved a territorial male), and the high level of vigilance exhibited by territorial males. A similar lack of observed copulations and a large proportion of pups not assigned a father was also proposed as suggestive of alternate mating tactics in the Galápagos sea lion [7].

As shown here, genetic analyses of paternity are critical to reveal true mating dynamics, as behavioral patterns may be misleading. For California sea lions, the maintenance of male territorial displays and behavioral observations were taken as indication of a

\section{References}

1. Clutton-Brock TH, Harvey PH (1978) Mammals, resources and reproductive strategies. Nature 273: 191-195.

2. Clutton-Brock TH, Vincent ACJ (1991) Sexual selection and the potential reproductive rate of males and females. Nature 351: 58-60.

3. Emlen ST, Oring LW (1977) Ecology, sexual selection, and the evolution of mating systems. Science 197: 215-223

4. Hughes C (1998) Integrating molecular techniques with field methods in studies of social behaviour: a revolution of results. Ecology 79: 383-399.

5. Cerchio S, Jacobson JK, Cholewiak DM, Falcone EA, Merriwether DA (2005) Paternity in humpback whales, Megaptera novaengliae: assessing polygyny and skew in male reproductive success. Animal Behaviour 70: 267-277.

6. McEachern MB, MeElreath RL, Van Vuren DH, Eadie JM (2009) Another genetically prommiscuous 'polygynous' mammal: mating system variation in Neotoma fuscipes. Animal Behaviour 77: 449-455.

7. Pörschmann U, Trillmich F, Mueller B, Wolf JBW (2010) Male reproductive success and its behavioural correlates in a polygynous mammal, the Galápagos sea lion (Zalophus wollebaeki). Molecular Ecology 19: 2574-2586.

8. Riedman M The pinnipeds: seals, sea lions, and walruses (University of California Press, Berkeley).

9. Bartholomew GA (1970) A model for the evolution of pinniped polygyny. Evolution 24: 546-549.

10. Boness DJ (1991) in Behavior of Pimmipeds, Renouf D, ed. (Chapman \& Hall, London). pp 1-44.

11. Cassini MH (1999) The evolution of reproductive systems in pinnipeds. Behavioral Ecology 10: 612-616.

12. Cassini MH (2000) A model of female breeding dispersion and the reproductive systems of pinnipeds. Behavioral Processes 51: 93-99.

13. Le Boeuf BJ (1991) in Behaviour of pimmipeds, ed. D. R, ed. (Chapman and Hall, London). pp 45-65.

14. Odell DK (1975) Breeding biology of the California sea lion. Rapports et ProcesVerbaux des Réunions Conseil International pour l'Exploration de la Mer 169: 374-378.

15. Trillmich F, Trillmich KGK (1984) The mating systems of pinnipeds and marine iguanas: convergent evolution of polygyny. Biological Journal of the Linnean Society 21: 209-216.

16. Carretta JV, Forney KA, Muto MM, Barlow J, Baker J, et al. (2007) ed. Department of Commerce, NOaAA. pp 1-7.

17. Szteren D, Aurioles-Gamboa D, Gerber LR (2006) in Sea lions of the world, Trites AW, Atkinson SP, D.P. D, eds. (Alaska Sea Grant College Program. University of Alaska, Fairbanks, Fairbanks, Alaska). pp 369-403.

18. García-Aguilar MC, Aurioles-Gamboa D (2003) Breeding season of the California sea lion (Zalophus califormianus) in the Gulf of California, Mexico. Aquatic Mammals 29: 10.

19. Heath C (1989) The behavioral ecology of the California sea lion, Zalophus Califormianus. PhD Disertation, University of California, Santa Cruz. 255 p.

20. Ridgeway SH, Harrison RJ Handbook of marine mammals (Academic Press, New York).

21. Robertson KL, Runcorn CW, Young JK, Gerber LR (2008) Spatial and temporal patterns of terriotory use of male California sea lions (Zalophus lek-like mating system, where females show preference for certain males based on territorial displays or territory location and few males sire the majority of the pups [19]. However, our paternity analyses revealed a level of variation in male reproductive success much lower than expected in a lek-like mating system [24]. Instead, California sea lions in the Gulf appear to exhibit very weak polygyny, in which the function of territorial defense and the potential existence of alternative mating strategies remain to be clarified.

\section{Acknowledgments}

We thank the lobos field crews from 2005-2008 for their work in the field and the Centro Intercultural de Estudios de Desiertos y Océanos for the use of their facilities and hospitality. Dr. Phil Hedrick and Dr. Tom Dowling generously provided advice and access to their laboratories at Arizona State University.

\section{Author Contributions}

Conceived and designed the experiments: MG JY LG RF CH. Performed the experiments: RF MG CH JY. Analyzed the data: RF JY AI. Contributed reagents/materials/analysis tools: LG. Wrote the paper: RF MG JY LG CH.

californianus) in the Gulf of California, Mexico. Canadian Journal of Zoology 86: 237-244.

22. Jacobs DF, Hernández-Camacho CJ, Young JK, Gerber LR (2008) Determinants of outcomes of agonistic interactions among male California sea lions (Zalophus californianus). Journal of Mammalogy 89: 1212-1217.

23. Young JK, Gerber LR (2008) The influence of social composition on reproductive behavior of territorial male California sea lions. Aquatic Mammals 34: $102-108$.

24. Shuster SM, Wade MJ Mating Systems and Strategies (Princeton University Press, Princeton).

25. Weckerly FW (1998) Sexual-size dimorphism: influence of mass and mating systems in the most dimorphic mammals. Journal of Mammalogy 79: 33-52.

26. Aurioles-Gamboa D (1988) Behvioral ecology of California sea lions in the Gulf of California. PhD dissertation, University of California, Santa Cruz, California.

27. Odell DK (1974) Behavioral thermoregulation in the California sea lion. Behavioral Biology 10: 231-237.

28. Gerber LR, Young JK, Gonzalez-Suarez M, Hernandez-Camacho CJ, Sabo JL (2010) The cost of male aggression and polygyny in California sea lions (Zalophus californianus). PLoS ONE 5: e12230.

29. Jacobs DF, Hernandez-Camacho GJ, Young JK, Gerber LR (2008) Determinates of outcomes of agnostic interactions among male California sea lions (Zalophus californianus). Journal of Mammalogy 89: 1212-1217.

30. Young JK, Gerber LR (2008) The influence of social composition on reproductive behavior of territorial male California sea lions. Aquatic Mammals 34: 103-110.

31. González-Suárez M, Gerber LR (2008) Habitat preferences of California sea lions: implications for conservation. Journal of Mammalogy 89: 1521-1528.

32. Hoberecht LK, Vos DJ, VanBlaricom GR (2006) A remote biopsy system used to sample steller sea lion (Eumetopias jubatus) blubber. Marine Mammal Science 22: 683-689.

33. Flatz R, Gerber LR (2010) First evidence for adoption in California sea lions. PLoS ONE 5: e13873.

34. Miller SA, Dykes DD, Polesky HF (1988) A simple salting out procedure for extracting DNA from human nucleated cells. Nucleic Acids Research 16: 1215.

35. Valiere W (2002) GIMLET: a computer program for analysing genetic individual identification data. Molecular Ecology Notes 2: 377-379.

36. Marshall TC, Slate J, Kruuk LEB, Pemberton JM (1998) Statistical confidence for liklihood-based paternity inference in natural populations. Molecular Ecology 7: 639-655.

37. Hoffman JI, Amos W (2005) Microsatellite genotyping errors: detection approaches, common sources, and censequences for paternal exclusion. Molecular Ecology 14: 599-612.

38. Taberlet P, Waits LP, Luikart G (1999) Noninvasive genetic sampling: look before you leap. Trends in Ecology and Evolution 14: 323-327.

39. Hoffman JI, Boyd IL, Amos W (2003) Male reproductive strategy and the importance of maternal status in the Antarctic fur seal Arctocephalus gazella. Evolution 57: 1917-1930.

40. Le Boeuf BJ (1986) Sexual strategies of seals and walruses. New Scientist 1491: 36-39. 
41. Twiss SD, Poland VF, Graves JA, Pomeroy PP (2006) Finding fathers: spatiotemporal analysis of paternity assignment in grey seals (Halichoerus grypus). Molecular Ecology 15: 14.

42. Villegas-Amtmann S, Atkinson S, Costa DP (2009) Low synchrony in the breeding cycle in Galápagos sea lions revealed by seasonal progesterone concentrations. Journal of Mammalogy 90: 1232-1237.

43. Trillmich F Fur seals: maternal strategies on land and sea (Princeton University Press, Princeton).

44. González-Suárez M, Flatz R, Aurioles-Gamboa D, Hedrick PW, Gerber LR (2009) Isolation by distance among California sea lion populations in Mexico: redefining management stocks. Molecular Ecology 18: 1088-1099.

45. Hoffman JI, Forcada J, Trathan PN, Amos W (2007) Female fur seals show active choice for males that are heterozygous and unrelated. Nature 445: 912-914.

46. Soto KH, Trites AW (2011) South American sea lions in Peru have a lek-like mating system. Marine Mammal Science 27: 306-333.

47. Gross MR (1996) Alternative reproductive strategies and tactics: diversity within sexes. Trends in Ecology and Evolution 11: 92-98.

48. Plaistow SJ, Johnstone RA, Colegrave N, Spencer M (2004) Evolution of alternative mating tactics: conditional versus mixed strategies. Behavioral Ecology 15: 534-542.

49. Bruyn PJN, Tosh CA, Bester MN, Cameron EZ, McIntyre T, et al. (2011) Sex at sea: alternative mating system in an extremely polygynous mammal. Animal Behaviour 82: 445-451.
50. Goodman SJ (1997) Dinucleotide repeat polymrphisms at seven anonymous microsatellite loci cloned from teh European harbour seal (Phoca vitulina vitulina). Animal Genetics 28: 310-311.

51. Hernandez-Velazquez FD, Galindo-Sanchez CE, Taylor MI, De La RosaVelez J, Cote IM, et al. (2005) New polymorphic microsatellite markers for California sea lions (Zalophus califormianus). Molecular Ecology Notes 5: 140-142.

52. Buchanan FC, Maiers LD, Thue TD, De March BGE, Stewart REA (1998) Microsatellites from the Atlantic walrus Odobenus rosmarus rosmarus. Molecular Ecology 7: 1083-1084

53. Wolf JBW, Tautz D, Caccone A, Steinfartz S (2006) Developement of new microsatellite loci and evaluation of loci from other pinniped species for the Galápagos sea lion (Zalophus californianus wollebaeki). Conservation Genetics 7: 461-465.

54. Coltman DW, Bowen WD, Wright JM (1996) PCR primers for harbor seal (Phoca vitulina concolour) microsatellites amplify polymorphic loci in other pnniped species. Molecular Ecology 5: 161-163.

55. Allen PJ, Amos W, Pomeroy PP, Twiss SD (1995) Microsatellite variation in grey seals, Halichoerus grypus: a study using DNA fingerprinting. Proceedings of the Royal Society of London Series B-Biology Sciences 252: 199-207.

56. Hubinger RM, Louis EEJ, Gelatt T, Rea LD, Bickham JW (2007) Characterization of eight microsatellite loci in Steller sea lions (Eumetopias jubatus). Molecular Ecology Notes 7: 1097-1099. 